\title{
Gambaran Karakteristik Pasien Erupsi Obat Alergi di RSUD Arifin Achmad Pekanbaru Periode 2010 - 2014
}

\author{
Endang H Darmani, ${ }^{1}$ T.Sy. Dessi Indah S As, ${ }^{1}$ Yuni Eka Anggraini, ${ }^{1}$ Olivia Makmur ${ }^{2}$
}

\begin{abstract}
Allergic drug eruptions is one of most dermatology cases can find in Arifin Achmad General Hospital Pekanbaru for last four years and study about the characteristic description of allergic drug eruption's patients never been described before. To describe the characteristic of allergic drug eruption's patients in Arifin Achmad General Hospital Pekanbaru Indonesia. This is a descriptive retrospective study with 35 subjects, which is describing the most common type of morphologic skin eruption, groups of gender and age were affected, and etiology drugs were suspected. Most common type of morphologic skin eruption is exfoliative dermatitis (eritroderma) $(42,8 \%)$, most frequently gender affected is women (60\%) and group of age most frequenly affected is 41-50 (25.7\%) years old. Antibiotics is the most causes were suspected (60\%). Exfoliative dermatitis, women and age 41-50 years old were most common characteristic description of allergic drug eruption's patients in Arifin Achmad general Hospital Pekanbaru time periode 20102014.
\end{abstract}

Keywords: allergic drug eruptions, gender, age, morphologic, antibiotic.

Reaksi kulit karena obat termasuk erupsi obat alergik banyak ditemukan. Kejadian ini meliputi 2 hingga 3 persen pasien rawat inap. ${ }^{1}$ Pada suatu studi, rerata erupsi obat pada kulit yang dirawat inap dilaporkan 2,2\% dengan persentase lebih tinggi pada pasien wanita, dan usia dewasa. ${ }^{2,3}$ Dari jumlah tersebut, reaksi obat yang serius didapatkan pada 1 dari 1000 orang yang dirawat inap. ${ }^{4}$ Insiden erupsi obat meningkat seiring dengan jumlah obat yang diresepkan dan adanya praktek polifarmasi. ${ }^{1,3}$ Faktor risiko yang berhubungan dengan reaksi hipersensitivitas obat adalah usia, jenis kelamin, penyakit yang mendasari, dan riwayat hipersensitivitas terhadap obat sebelumnya. ${ }^{3,5}$ Pasien dengan erupsi obat alergi memberikan dampak pada beban ekonomi dan lebih jauh dapat berefek buruk pada keselamatan jiwa individu. ${ }^{3,4}$ Bentuk erupsi obat alergi pada kulit yang umum ditemui adalah rash pada kulit, urtikaria, fixed drug eruption (FDE),

Penulis untuk korespondensi :

1 Department of Dermatology and Venereology Medical Faculty of Riau University, Arifin Achmad General Hospital Pekanbaru- Indonesia

2 Medical Faculty of Riau University

Alamat : Jl. Diponegoro No. 1 Telp. 0761-839264, ext 209 dan angioedema. Reaksi yang lebih serius dan membahayakan jiwa adalah Stevens-Johnson's syndrome (SJS), toxic epidermal necrolysis (TEN), drug reaction with eosinophilia and systemic symptoms (DRESS) dan acute generalized exanthematous pustulosis (AGEP), dan eritroderma. ${ }^{6}$

Hampir semua obat dapat menginduksi reaksi kulit, akan tetapi kelas obat tertentu yang mempunyai angka erupsi obat hingga $1-5 \%$, termasuk di dalamnya antiinflamasi non-steroid, antibiotik, dan antiepilepsi. ${ }^{7} \mathrm{Hal}$ ini serupa dengan sebuah penelitian systematic review di India, obat yang banyak menimbulkan erupsi alergi adalah antibiotik disusul oleh anti inflamasi non steroid (AINS), dan jenis erupsi terbanyak yang didapat adalah erupsi makulopapular (32,39\%) dan fixed drug eruption $(20,13 \%) .{ }^{6}$ Studi berbeda yang dilakukan di Iran memperlihatkan bahwa jenis terbanyak adalah eritroderma $(41,4 \%)$ dan erupsi makulopapular (26\%), sedangkan obat-obatan yang paling banyak menyebabkan erupsi adalah golongan antikonvulsan (20-30\%) dan antibiotik golongan sulfonamid (15-25\%). ${ }^{8}$ Penelitian pada 5 institusi rumah sakit di Bangkok menemukan bahwa obat- 
obatan antibiotik golongan sefalosporin menjadi penyebab terbanyak dan erupsi makulopapular merupakan jenis erupsi obat yang mendominasi hasil penelitian. ${ }^{9}$ Penelitian di Pakistan mengidentifikasi penyebab obat dengan jenis erupsi yang terjadi, yaitu cepharadine bertanggungjawab terjadinya erupsi makulopapular, golongan sulfonamid untuk SJS, anti inflamasi non-steroid untuk urtikaria, dan parasetamol untuk fixed drug eruption. ${ }^{3}$ Variasi penelitian ini dapat berhubungan dengan adanya pola penggunaan obat yang berbeda dan karakteristik kelompok etnis yang berbeda. ${ }^{8}$

Penelitian mengenai karakteristik pasien dengan erupsi obat alergi di Rumah Sakit Umum Daerah (RSUD) Arifin Achmad belum pernah dilakukan sebelumnya, sehingga tidak banyak informasi mengenai angka kejadian kasus. Hal ini yang mendorong penelitian dilakukan.

Tujuan umum penelitian untuk mengetahui gambaran karakteristik pasien erupsi obat alergi di RSUD Arifin Achmad periode 2010 - 2014.

\section{METODE}

Metode penelitian deskriptif retrospektif menggunakan data sekunder yang ada pada rekam medis RSUD Arifin Achmad periode 2010 - 2014

\section{HASIL}

Pada penelitian ini telah dilakukan pengambilan data sekunder dari rekam medis pasien-pasien yang menderita erupsi obat alergik di Staf Medis Fungsional (SMF) Kulit dan Kelamin RSUD Arifin Achmad dari tahun 2010 -2014.

Karakteristik subyek pada penelitian ini ditampilkan berdasarkan distribusi kelompok jenis kelamin, umur, morfologi erupsi kulit dan faktor penyebab yang dibagi menjadi dua bagian besar kelompok antibiotikdan non-antibiotik.
Tabel 1. Karakteristik subyek penelitian berdasarkan jenis kelamin

\begin{tabular}{rcc}
\hline & \multicolumn{2}{c}{$\begin{array}{c}\text { Subyek Penelitian } \\
\text { Kasus erupsi obat alergik }\end{array}$} \\
\cline { 2 - 3 } & $\mathrm{n}$ & $\%$ \\
\hline Jenis Kelamin & & \\
- Laki-laki & 14 & 40 \\
- Perempuan & 21 & 60 \\
\hline Total & 35 & 100 \\
\hline
\end{tabular}

Berdasarkan tabel 1 dari total 35 subjek penelitian laki-laki berjumlah 21 orang $(60 \%)$, sementara perempuan 14 orang (40\%).

Tabel 2. Karakteristik subyek penelitian berdasarkan kelompok usia

\begin{tabular}{ccc}
\hline & \multicolumn{2}{c}{ Subyek Penelitian } \\
\cline { 2 - 3 } Usia (tahun) & $\mathrm{N}$ & $\%$ \\
\hline $1-10$ & 5 & 14,28 \\
$11-20$ & 8 & 22,86 \\
$21-30$ & 6 & 17,14 \\
$31-40$ & 5 & 14,28 \\
$41-50$ & 9 & 25,7 \\
$51-60$ & 1 & 2,86 \\
$61-70$ & 1 & 2,86 \\
\hline Total & 35 & 100 \\
\hline
\end{tabular}

Berdasarkan tabel 2 dari total 35 subjek penelitian kelompok umur terbanyak yang menderita erupsi alergik obat adalah 41-50 tahun sebanyak $25,7 \%$.

Tabel 3. Karakteristik subyek penelitian berdasarkan jenis morfologi erupsi

\begin{tabular}{|c|c|c|}
\hline Jenis morfologi & $\mathrm{N}$ & $\%$ \\
\hline $\begin{array}{ll}\text { - } & \text { Urtikaria } \\
\text { - } & \text { Sindroma steven } \\
& \text { johnson } \\
\text { - } & \text { Eritroderma } \\
\text { - } & \text { FDE } \\
\text { - } & \text { Erupsi } \\
& \text { Akneformis } \\
\text { - } & \text { Exanthematosa } \\
& \text { Total }\end{array}$ & $\begin{array}{c}7 \\
5 \\
15 \\
3 \\
1 \\
4\end{array}$ & $\begin{array}{c}20 \\
14,28 \\
42,8 \\
8,57 \\
2,86 \\
11,43\end{array}$ \\
\hline
\end{tabular}


Berdasarkan tabel 3 dari total 35 orang subyek penelitian, jenis morfologi erupsi obat terbanyak adalah eritroderma (dermatitis eksfoliatif) sebanyak 15 orang $(42,8 \%)$

Tabel 4. Karakteristik Subjek penelitian berdasarkan jenis obat yang dicurigai sebagai penyebab

\begin{tabular}{llcc}
\hline & Jenis obat & $\mathrm{n}$ & $\%$ \\
\hline - & Antibiotik & 21 & 60 \\
- Non antibiotik & 14 & 40 \\
\hline Total & 35 & 100
\end{tabular}

Berdasarkan tabel 4 dari total 35 orang subyek penelitian, jenis obat yang dicurigai terbanyak adalah golongan antibiotik dengan jumlah 21 (60\%).

\section{PEMBAHASAN}

Berdasarkan hasil penelitian yang dapat dilihat dari tabel 1 , jenis kelamin perempuan merupakan yang terbanyak (60\%) menderita erupsi obat alergik di RSUD Arifin Achmad Pekanbaru pada kurun waktu 2010-2014. Studi di Amerika Serikat menunjukkan prevalensi erupsi obat alergi sebanyak $2-5 \%$ untuk pasien rawat inap dan $1 \%$ untuk pasien rawat jalan dan jenis kelamin wanita lebih prevalen dibanding pria. Hal yang sama juga didapat secara internasional dimana prevalensi erupsi obat alergik 2-3\% dari pasien rawat inap dan jenis kelamin wanita lebih prevalen. ${ }^{12}$

Berdasarkan hasil penelitian yang dapat dilihat dari tabel 2, kelompok usia 41-50 tahun adalah terbanyak menderita erupsi obat alergik di RSUD Arifin Achmad Pekanbaru kurun waktu 2010-2014. Sesuai dengan kepustakaan pada suatu studi dari jumlah prevalensi 2,2\% pasien erupsi obat alergik yang terbanyak adalah kelompok usia dewasa $(2,3 \%)$. Studi lain mengatakan erupsi obat alergi tipe tertentu seperti erupsi obat tipe Exantematosa jarang terjadi pada kelompok usia anak-anak. ${ }^{8}$

Berdasarkan hasil penelitian yang dapat dilihat dari tabel 3, jenis morfologi erupsi kulit eritroderma adalah terbanyak pada pasien erupsi obat alergik di RSUD Arifin Achmad Pekanbaru kurun waktu 20102014. Hal ini sesuai dengan suatu kepustakaan yang menyebutkan obat-obatan baik topikal dan sistemik secara signifikan berperan dalam terjadinya eritroderma. Sebanyak $15 \%$ dari eritroderma disebabkan oleh obat-obatan. ${ }^{13}$

Berdasarkan hasil penelitian yang dapat dilihat dari tabel 4 jenis obat penyebab terbanyak dari erupsi obat alergik adalah golongan antibiotik (60\%). Hal ini sesuai dengan kepustakaan, suatu sistematik preview menunjukkan bahwa penyebab terbanyak dari erupsi obat alergi adalah antibiotik. ${ }^{13}$

\section{KESIMPULAN}

Jenis kelamin terbanyak pasien erupsi obat alergi yang berobat di RSUD Arifin Achmad tahun 2010-2014 adalah perempuan dengan kelompok usia terbanyak adalah 41-50 tahun. Morfologi kulit terbanyak pasien erupsi obat alergi adalah eritroderma dengan jenis obat terbanyak yang disangkakan pasien erupsi obat alergi adalah antibiotik.

\section{DAFTAR PUSTAKA}

1. Gruchalla R. Understanding drug allergies. J Allergy Clin Immunol.

2. Raut A, Pawar A, Pankaj M, Srivastava P, Mishra A. Clinical pattern and severity of cutaneous adverse drug reactions. Int J Pharm Pharm Sci. 2013;5(Suppl 2):612-6.

3. Hasan R, Akhtar N, Begum M, Ali ME. Cutaneous morphological patterns of adverse drug reactions/ : a study of 50 cases. J Pakistan Assoc Dermatol. 2010;20:206-11.

4. Lazarou J, Pomeranz BH, Corey PN. Incidence of adverse drug reactions in hospitalized patients: a meta-analysis of prospective studies. JAMA. 1998;279(15):1200-5.

5. Riedl MA, Casillas AM. Adverse drug reactions. Lancet. 2000;356(9237):1212.

6. Lee A, Thomson J. Drug-induced skin reactions. Pharm J. 1999;262(7036):357-65. 
7. Patel TK, Thakkar SH, Sharma D. Cutaneous adverse drug reactions in Indian population: A systematic review. Indian Dermatol Online J. 2014;5(Suppl 2):S76-86.

8. Jelvehgari M, Azimi H, Montazam H. Prevalence of cutaneous drug eruption in hospitalized patients: A report from Sina Hospital of Tabriz Mitra. Iran J Dermatol. 2010;46(4):93-100.

9. Puavilai S, Noppakun N, Sitakalin C, Leenutaphong V, Wattanakrai P, Nakakes A, et al. Drug eruptions at five institutes in Bangkok. J Med Assoc Thail. 2005;88(11):1642-50.
10.Blume EJ. Drug Eruption available at http// emediate mediscape diperbarui terakhir tanggal 9 Oktober 2015.

11. Gran kels JM, Fedeles F, Rothe MJ. Exfoliative dermatitis. In fitzpatricks dermatology in general medicine goldsmith LA, fatz SI, Gilchirest BA, Paller AS, leffell DJ, Wolff eds \& editor. MGrawlill. Newyork. 2008.p.267 